\title{
EVALUASI PENERAPAN ASPEK MATERIAL RESOURCES AND CYCLE SESUAI STANDAR GREEN BUILDING RATING TOOL FOR NEW BUILDING VERSION 1.2 PADA PROYEK BANGUNAN GEDUNG
}

\author{
oleh : \\ Qibthia Fahnurlisa \\ PT. Dacrea Design and Engineering Consultant \\ Email : qibthiafahnurlisa@gmail.com
}

\begin{abstract}
Abstrak: Bangunan berkonsep ramah lingkungan menjadi kebutuhan yang sangat penting untuk Indonesia saat ini. Pencemaran terhadap lingkungan dan penggunaan sumber daya alam tidak dapat dikontrol, sehingga memberikan dampak tidak baik bagi lingkungan. Untuk itu di Indonesia mulai diterapkan standar konsep green bulding dengan sistem rating yang bernama greenship rating tool (standar untuk tolok ukur bangunan ramah lingkungan) yang di keluarkan oleh Green Building Council Indonesia (GBCI). Salah satu aspek yang harus dipenuhi adalah material resources and cycle (MRC) yang memiliki 7 kategori aspek sesuai standar green building rating tool tersebut. Tujuan penelitian ini salah satunya untuk mengidentifikasi kesesuaian persyaratan pada standar sistem green building rating tool for new building version 1.2 dengan objek bangunan gedung yang ditinjau. Penelitian ini menggunakan metode survey. Metode survey dimaksudkan untuk mendapatkan data dari tempat penelitian secara alamiah, dengan peneliti melakukan perlakuan dalam pengumpulan datanya seperti penyebaran kuesioner kepada responden yang dituju (berjumlah 30 responden). Hasil pada penelitian ini terdapat 3 sub variabel yang memiliki korelasi pada level sangat kuat, yaitu : sub variabel A1 (Penggunaan refrigeran non-chloro fluoro carbon (CFC) dan pemadam kebakaran non-halon), sub variabel G1 (Penggunaan material yang lokasi asal bahan baku utama atau fabrikasinya berada di dalam radius $1.000 \mathrm{~km}$ dari lokasi proyek) dan sub variabel G2 (Penggunaan material yang lokasi asal bahan baku utama atau fabrikasinya berada dalam wilayah RI). Sedangkan untuk kategori dominan (peringkat pertama) sesuai standar green building rating tool for new building version 1.2 yang telah diterapkan pada bangunan gedung peneliti tinjau adalah sub variabel A1 (Penggunaan refrigeran non-chloro fluoro carbon (CFC) dan pemadam kebakaran non-halon). Dengan nilai rata-rata hasil validasi penelitian (3 responden) terhadap hasil rata-rata pada sampel (30 responden) memperoleh nilai yang sama yaitu angka 4 dimana dalam skala likert angka 4 mempunyai arti setuju pada hasil analisa data yang didapat pada penelitian ini. Sehingga dapat disimpulkan kategori aspek material resources and cycle (MRC) pada objek bangunan gedung yang ditinjau telah sesuai dengan persyaratan standar green building rating tool for new building version 1.2.
\end{abstract}

Kata kunci : Aspek material resources and cycle, standar green building

Abstract : Environmentally friendly buildings are very important needs for Indonesia today. Pollution of the environment and the use of natural resources cannot be controlled, so that it gives a bad impact on the environment. For this reason, in Indonesia a green bulding concept standard has been adopted with a rating system called the greenship rating tool (a standard for environmentally friendly building benchmarks) issued by the Green Building Council Indonesia (GBCI). One aspect that must be met is the material resources and cycle (MRC) which has 7 aspects categories according to the standard green building rating tool. The purpose of this study is to identify the suitability of the requirements of the green building rating system standard tool for new building version 1.2 with the building object being reviewed. This research uses survey method. The survey method is intended to obtain data from the study site naturally, with researchers treating the collection of data such as the distribution of questionnaires to the intended respondents (totaling 30 respondents). The results in this study there are 3 sub-variables that have a very strong correlation, namely: 
sub-variable $A 1$ (use of non-chloro fluoro carbon refrigerant (CFC) and non-halon fire extinguisher), subvariable $G 1$ (use of material from the location of material origin the main raw material or fabrication is within a radius of 1,000 km from the project site) and sub-variable G2 (the use of materials where the main raw material or fabrication location is within the territory of RI). Whereas the dominant category (first rank) according to the standard green building rating tool for new building version 1.2 that has been applied to the building of the research building is sub variable A1 (Use of non-chloro fluoro carbon (CFC) refrigerant and non-halon fire extinguisher). With the average value of the results of research validation (3 respondents) to the average results in the sample (30 respondents) get the same value which is number 4 where in the likert scale number 4 has the meaning of agreeing on the results of data analysis obtained in this study. So it can be concluded that the category of material resources and cycle (MRC) aspects of the object of the building being reviewed is in accordance with the standard requirements of the green building rating tool for new building version 1.2 .

Keyword: Material aspects resources and cycle, standar green building

\section{Pendahuluan}

Material merupakan proses berlangsungnya masukan (input) berupa sumber daya alam hingga menghasilkan keluaran (output) berupa produk. Selain itu, proses tersebut memberikan dampak ekologi yang cukup luas baik selama proses pembentukan berlangsung maupun pada saat penggunaan. Dengan tujuan penerapan bangunan berkonsep ramah lingkungan, pembangunan pastinya lebih ekonomis, lebih efisien dan bermanfaat untuk penghuni bangunan itu sendiri ataupun lingkungan sekitarnya tanpa adanya pengerusakan lingkungan, karena green building merupakan pembangunan yang menggunakan material-material secara lokal ataupun limbah produksi serta material-material bersertifikat dan material yang melalui proses ramah lingkungan.

\section{Tujuan Penelitian}

a. Untuk mengetahui pengaruh standar sistem green building rating tool for new building version 1.2 terhadap aspek sumber dan suklus material (material resources and cyle)pada bangunan ramah lingkungan khususnya proyek bangunan gedung yang ditinjau b. Untuk mengetahui kategori manakah yang dominan dalam pemahaman konsep dan praktik tentang bangunan ramah lingkungan pada proyek bangunan gedung yang ditinjau sesuai standar sistem green building rating tool for new building version 1.2

c. Untuk mengidentifikasi kesesuaian persyaratan pada standar sistem green building rating tool for new building version 1.2 dengan objek bangunan gedung yang ditinjau

\section{Manfaat Penelitian}

a. Usaha memperluas wawasan terhadap penerapan green building di Indonesia sesuai standar green building rating tool for new building version 1.2.

b. Penelitian ini diharapkan dapat dijadikan percontohan dalam mendesain bangunan yang berkonsep green building dengan standar nasional yang telah disesuaikan dengan iklim tropis di Indonesia, dilihat dari segi materialnya.

c. Solusi bagi dunia konstruksi untuk menghasilnya produk material yang baik bagi pengguna bangunan maupun lingkungan sekitar. 


\section{Konsep Green Building}

Dalam konsep ramah ligkungan atau ramah lingkungan, gedung tidak lagi hanya dipandang sebagai sebuah karya arsitektur semata tetapi harus dipandang sebagai sebuah objek yang juga memiliki daur hidup seperti makhluk hidup. Definisi green buiding menurut Chen (2008) adalah sebuah bangunan yang dalam pemanfaatannya (baik sejak direncanakan, didesain, dibangun, digunakan, maupun direnovasi) menggunakan sumber daya alam dan sumber energi secara minimalis, meminimalisasi limbah, dan ramah lingkungan.

Menurut Pitts (2004), green buiding merupakan konsep yang menjadi solusi bagi dunia properti untuk mengambil peran dalam mengurangi dampak pada global warming.

Menurut Jimmy (2008), konsep green building tidak lepas kaitannya dengan efisiensi penggunaan energi tetapi juga air, melestarikan sumber daya alam dan meningkatkan kualitas udara.

Menurut Peraturan Menteri Negara Lingkungan Hidup Nomor 8 Tahun 2010 Tentang Kriteria dan Sertifikasi Bangunan Ramah Lingkungan Bab 1 Pasal 1, bangunan ramah lingkungan (green building) adalah suatu bangunan yang menerapkan prinsip lingkungan dalam perancangan, pembangunan, pengoperasian, dan pengelolaannya dan aspek penting penanganan dampak perubahan iklim. Prinsip lingkungan yang dimaksud adalah prinsip yang mengedepankan dan memperhatikan unsur pelestarian fungsi lingkungan.

\section{Aspek Material Resources And Cycle}

Material adalah zat atau benda yang dari mana sesuatu dapat dibuat darinya, atau barang yang dibutuhkan untuk membuat sesuatu (Ashby, Shercliff, \& Cebon, 2007). Sumber daya (Resources)adalah suatu nilai potensi yang dimiliki oleh suatu materi atau unsur tertentu dalam kehidupan.

Aspek material resources and cycle terdiri dari :

1. Refrigeran Fundamental (Fundamental Refrigerant)

2. Penggunaan Gedung Dan Material Bekas (Building And Material Reuse)

3. Material Melalui Proses Ramah Lingkungan(Environmentally Friendly Processed Material)

4. Penggunaan Bahan Yang Tidak Mengandung Bahan Perusak Ozon / BPO (Non-ODS Usage)

5. Kayu Bersertifikat (Certified Wood)

6. Material Pra Fabrikasi (Prefab Material)

7. Material Regional (Regional Material)

\section{Uji Validitas dan Reliabilitas}

Validitas berasal dari kata validity yang mempunyai arti sejauh mana ketepatan dan kecermatan suatu alat ukur dalam melakukan fungsi ukurannya (Azwar 1986) Uji reabilitas, menurut Sumadi Suryabrata (2004: 28) reabilitas menunjukkan sejauh mana hasil pengukuran dengan alat tersebut dapat dipercaya.

\section{Analisa Statistik Deskriptif}

Analisis ini memiliki kegunaan untuk menyajikan karakteristik suatu data dari sampel tertentu sehingga peneliti mengetahui secara cepat gambaran sekilas dan ringkas dari data yang telah diperoleh.

\section{Analisa Korelasi Spearman}

Korelasi adalah istilah statistik yang menyatakan derajat hubungan linier antara dua valiabel atau lebih. Hubungan antara dua variabel di dalam teknik korelasi 
bukanlah dalam arti hubungan sebab akibat (timbal balik), melainkan hanya merupakan hubungan searah saja. Sebagai pedoman sederhana angka korelasi diatas 0,5 menunjukkan korelasi kuat, sedangkan di bawah 0,5 menunjukkan korelasi lemah.

\section{Analisa Regresi}

Analisis regresi adalah analisis lanjutan dari korelasi, analisis regresi dilakukan untuk menguji sejauh mana pengaruh variabel independent terhadap variabel dependent setelah dilakukan uji korelasi dan ternyata adanya hubungan antara variabel tersebut.

\section{Hasil Penelitian}

Untuk hal tersebut dibutuhkan kuesioner pada penelitian dan dapat diujikan secara statistik. Adapun untuk kuesioner ditampilkan pada tabel berikut.

\section{Tabel 1. Kuesioner dan variabelnya}

\begin{tabular}{|c|c|c|c|c|}
\hline No & Variabel & & ub Variabel & Tolak Ukur \\
\hline$A$ & $\begin{array}{l}\text { Prasyara } \\
\mathrm{t} \\
\text { Fundam } \\
\text { ental } \\
\text { Refriger } \\
\text { ant }\end{array}$ & $\mathrm{A} 1$ & $\begin{array}{l}\text { Penggunaan } \\
\text { refrigeran non- } \\
\text { chloro fluoro } \\
\text { carbon (CFC) } \\
\text { dan pemadam } \\
\text { kebakaran non- } \\
\text { halon) }\end{array}$ & $\begin{array}{l}\text { Tidak } \\
\text { menggunakan } \\
\text { chloro fluoro- } \\
\text { carbon (CFC) } \\
\text { sebagai refrigeran } \\
\text { dan halon sebagai } \\
\text { bahan pemadam } \\
\text { kebakaran }\end{array}$ \\
\hline$B$ & $\begin{array}{l}\text { MRC } 1 \\
\text { (Building } \\
\text { And } \\
\text { Material } \\
\text { Reuse) }\end{array}$ & B1 & $\begin{array}{l}\text { Penggunaan } \\
\text { kembali } \\
\text { material bekas, } \\
\text { baik dari } \\
\text { bangunan lama } \\
\text { atau dari } \\
\text { tempat lain, } \\
\text { berupa bahan } \\
\text { struktur utama, } \\
\text { fasad, plafon, } \\
\text { lantai, partisi, } \\
\text { kusen dan } \\
\text { dinding }\end{array}$ & $\begin{array}{l}\text { Menggunakan } \\
\text { kembali material } \\
\text { bekas, baik dari } \\
\text { bangunan lama } \\
\text { maupun tempat } \\
\text { lain, berupa } \\
\text { bahan struktur } \\
\text { utama, fasad, } \\
\text { plafon, lantai, } \\
\text { partisi, kusen, dan } \\
\text { dinding, setara } \\
\text { minimal } 10 \% \text { dan } \\
20 \% \text { dari total } \\
\text { biaya material }\end{array}$ \\
\hline
\end{tabular}

\begin{tabular}{|c|c|c|c|c|}
\hline No & Variabel & \multicolumn{2}{|r|}{ Sub Variabel } & Tolak Ukur \\
\hline \multirow[t]{3}{*}{$\mathrm{C}$} & \multirow[t]{3}{*}{$\begin{array}{l}\text { MRC 2 } \\
\text { (Environ } \\
\text { mentally } \\
\text { Friendly } \\
\text { Processe } \\
\text { d } \\
\text { Material } \\
\text { ) }\end{array}$} & C1 & $\begin{array}{l}\text { Penggunaan } \\
\text { material yang } \\
\text { bersertifikat ISO } \\
14001 \text { terbaru } \\
\text { atau sertifikat } \\
\text { lain yang setara }\end{array}$ & $\begin{array}{l}\text { Menggunakan } \\
\text { material yang } \\
\text { memiliki sertifikat } \\
\text { sistem } \\
\text { manajemen } \\
\text { lingkungan pada } \\
\text { proses } \\
\text { produksinya } \\
\text { minimal bernilai } \\
30 \% \text { dari total } \\
\text { biaya material. }\end{array}$ \\
\hline & & $\mathrm{C} 2$ & $\begin{array}{l}\text { Penggunaan } \\
\text { material yang } \\
\text { merupakan } \\
\text { hasil daur ulang }\end{array}$ & $\begin{array}{l}\text { Menggunakan } \\
\text { material yang } \\
\text { merupakan hasil } \\
\text { proses daur ulang } \\
\text { minimal bernilai } \\
5 \% \text { dari total } \\
\text { biaya material }\end{array}$ \\
\hline & & C3 & $\begin{array}{l}\text { Penggunaan } \\
\text { material yang } \\
\text { bahan baku } \\
\text { utamanya } \\
\text { berasal dari } \\
\text { sumber daya } \\
\text { terbarukan } \\
\text { dengan masa } \\
\text { panen jangka } \\
\text { pendek <10 } \\
\text { tahun }\end{array}$ & $\begin{array}{l}\text { Menggunakan } \\
\text { material yang } \\
\text { bahan baku } \\
\text { utamanya berasal } \\
\text { dari sumber daya } \\
\text { (SD) terbarukan } \\
\text { dengan masa } \\
\text { panen jangka } \\
\text { pendek (<10 } \\
\text { tahun) minimal } \\
\text { bernilai } 2 \% \text { dari } \\
\text { total biaya } \\
\text { material }\end{array}$ \\
\hline D & $\begin{array}{l}\text { MRC } 3 \\
\text { (Non- } \\
\text { ODS } \\
\text { Usage) }\end{array}$ & D1 & $\begin{array}{l}\text { Tidak } \\
\text { menggunakan } \\
\text { bahan perusak } \\
\text { ozon pada } \\
\text { seluruh sistem } \\
\text { bangunan }\end{array}$ & $\begin{array}{l}\text { Tidak } \\
\text { menggunakan } \\
\text { bahan perusak } \\
\text { ozon (BPO) pada } \\
\text { seluruh sistem } \\
\text { pendingin gedung } \\
\text { (AC) }\end{array}$ \\
\hline $\mathrm{E}$ & $\begin{array}{l}\text { MRC 4 } \\
\text { (Certifie } \\
\text { d Wood) }\end{array}$ & E1 & $\begin{array}{l}\text { Penggunaan } \\
\text { bahan material } \\
\text { kayu yang } \\
\text { bersertifikat } \\
\text { legal sesuai } \\
\text { dengan } \\
\text { peraturan } \\
\text { pemerintah } \\
\text { tentang asal } \\
\text { kayu dan sah } \\
\text { terbebas dari } \\
\text { perdagangan } \\
\text { kayu illegal }\end{array}$ & $\begin{array}{l}\text { Menggunakan } \\
\text { bahan material } \\
\text { kayu yang } \\
\text { bersertifikat legal } \\
\text { sesuai dengan } \\
\text { Peraturan } \\
\text { Pemerintah } \\
\text { tentang asal kayu } \\
\text { (seperti faktur } \\
\text { angkutan kayu } \\
\text { olahan / FAKO, } \\
\text { sertifikat } \\
\text { perusahaan, dan } \\
\text { lain-lain) dan sah } \\
\text { terbebas dari } \\
\text { perdagangan kayu } \\
\text { ilegal sebesar } \\
\text { 100\% biaya total } \\
\text { material kayu }\end{array}$ \\
\hline
\end{tabular}




\begin{tabular}{|c|c|c|c|c|}
\hline \multirow[t]{2}{*}{ No } & \multirow[t]{2}{*}{ Variabel } & \multicolumn{2}{|r|}{ Sub Variabel } & \multirow{2}{*}{\begin{tabular}{l}
\multicolumn{1}{c}{ Tolak Ukur } \\
Sebesar $30 \%$ \\
penggunaan \\
bahan material \\
kayu yang sudah \\
bersertifikat legal
\end{tabular}} \\
\hline & & E2 & $\begin{array}{l}\text { Penggunaan } \\
\text { kayu / } \\
\text { bersertifikat } \\
\text { dari Lembaga } \\
\text { Ekolabel } \\
\text { Indonesia (LEI) } \\
\text { atau Forest } \\
\text { Stewardship } \\
\text { Council (FSC) }\end{array}$ & \\
\hline$F$ & $\begin{array}{l}\text { MRC 5 } \\
\text { (Prefab } \\
\text { Material } \\
\text { ) }\end{array}$ & F1 & $\begin{array}{l}\text { Penggunaan } \\
\text { material } \\
\text { modular atau } \\
\text { prafabrikasi }\end{array}$ & $\begin{array}{l}\text { Desain yang } \\
\text { menggunakan } \\
\text { material modular } \\
\text { atau pra fabrikasi } \\
\text { sebesar 30\% dari } \\
\text { total biaya } \\
\text { material }\end{array}$ \\
\hline \multirow[t]{2}{*}{ G } & \multirow[t]{2}{*}{$\begin{array}{l}\text { MRC 6 } \\
\text { (Regiona } \\
\text { I } \\
\text { Material } \\
\text { ) }\end{array}$} & G1 & $\begin{array}{l}\text { Penggunaan } \\
\text { material yang } \\
\text { lokasi asal } \\
\text { bahan baku } \\
\text { utama atau } \\
\text { fabrikasinya } \\
\text { berada di dalam } \\
\text { radius } 1.000 \mathrm{~km} \\
\text { dari lokasi } \\
\text { proyek }\end{array}$ & $\begin{array}{l}\text { Menggunakan } \\
\text { material yang } \\
\text { lokasi asal bahan } \\
\text { baku utama dan } \\
\text { pabrikasinya } \\
\text { berada di dalam } \\
\text { radius } 1.000 \mathrm{~km} \\
\text { dari lokasi proyek } \\
\text { minimal bernilai } \\
50 \% \text { dari total } \\
\text { biaya material }\end{array}$ \\
\hline & & G2 & $\begin{array}{l}\text { Penggunaan } \\
\text { material yang } \\
\text { lokasi asal } \\
\text { bahan baku } \\
\text { utama atau } \\
\text { fabrikasinya } \\
\text { berada dalam } \\
\text { wilayah RI }\end{array}$ & $\begin{array}{l}\text { Menggunakan } \\
\text { material yang } \\
\text { lokasi asal bahan } \\
\text { baku utama dan } \\
\text { pabrikasinya } \\
\text { berada dalam } \\
\text { wilayah Republik } \\
\text { Indonesia bernilai } \\
\text { minimal } 80 \% \text { dari } \\
\text { total biaya } \\
\text { material }\end{array}$ \\
\hline
\end{tabular}

Tabel 2. Hasil Validasi Kuesioner

\begin{tabular}{|c|c|c|c|c|c|c|c|c|c|c|c|}
\hline & \multicolumn{11}{|c|}{ Variabel } \\
\hline \multirow{2}{*}{ Responden } & A & B & \multicolumn{3}{|c|}{ c } & D & \multicolumn{2}{|c|}{$\mathrm{E}$} & $\mathrm{F}$ & \multicolumn{2}{|c|}{ G } \\
\hline & A1 & B1 & $\mathrm{C} 1$ & C2 & C3 & D1 & E1 & E2 & $\mathrm{F} 1$ & G1 & G2 \\
\hline 1 & 1 & 0 & 1 & 1 & 0 & 1 & 1 & 0 & 1 & 1 & 1 \\
\hline 2 & 1 & 1 & 1 & 1 & 0 & 1 & 1 & 0 & 1 & 1 & 1 \\
\hline 3 & 1 & 1 & 1 & 1 & 0 & 1 & 1 & 0 & 1 & 1 & 1 \\
\hline 4 & 1 & 0 & 1 & 1 & 1 & 1 & 1 & 1 & 1 & 1 & 1 \\
\hline 5 & 1 & 0 & 1 & 1 & 0 & 1 & 1 & 0 & 1 & 1 & 1 \\
\hline & 5 & 2 & 5 & 5 & 1 & 5 & 5 & 1 & 5 & 5 & 5 \\
\hline & 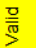 & 옹 & 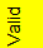 & 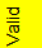 & 음 & $\frac{\underline{\underline{D}}}{\overline{\tilde{J}}}$ & $\frac{\underline{\underline{\nu}}}{\overline{\underline{J}}}$ & 옴 & 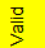 & 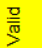 & 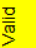 \\
\hline
\end{tabular}

Sumber : Hasil olahan penulis, 2017
Pengumpulan data tahap selanjutnya berdasarkan variabel yang disetujui (valid). Dan varibel yang tidak disetujui akan didrop (dihapus) dari tabel kuesioner.

\section{Kuesioner Tahap 2 (Responden = Kontraktor Pelaksana)}

Pengumpulan data tahap kedua ini merupakan penyebaran kuesioner kepada kontraktor pelaksana sebanyak 30 orang responden.

1. Uji Validitas dan Reliabilitas

Tabel 3. Output Uji Validitas

\begin{tabular}{|l|c|c|c|c|c|}
\hline & $\begin{array}{c}\text { Scale Mean } \\
\text { if Item } \\
\text { Deleted }\end{array}$ & $\begin{array}{c}\text { Scale } \\
\text { Variance } \\
\text { if Item } \\
\text { Deleted }\end{array}$ & $\begin{array}{c}\text { Corrected } \\
\text { Item-Total } \\
\text { Correlation }\end{array}$ & $\begin{array}{c}\text { Cronbach's } \\
\text { Alpha if } \\
\text { Item } \\
\text { Deleted }\end{array}$ & Validitas \\
\hline A1 & 25.77 & 24.599 & .608 & .800 & Valid \\
C1 & 27.53 & 20.602 & .668 & .785 & Valid \\
C2 & 25.67 & 25.402 & .480 & .813 & Valid \\
D1 & 26.07 & 21.720 & .577 & .800 & Valid \\
E1 & 26.53 & 23.982 & .371 & .832 & Valid \\
F1 & 27.50 & 20.534 & .677 & .784 & Valid \\
G1 & 25.90 & 25.334 & .500 & .811 & Valid \\
G2 & 25.73 & 24.616 & .648 & .798 & Valid \\
\hline
\end{tabular}

Sumber : Hasil olahan penulis, 2017

Berdasarkan tabel diatas, Nilai $r$ dicari menggunakan tabel $\mathrm{r}$ uji dua sisi dengan level signifikan 0.05. Untuk jumlah data (n) sebanyak 30, diperoleh nilai r sebesar 0.361. Nilai $r$ ini dibandingkan dengan nilai corrected item total correlation output. Jika nilai corrected item total correlation lebih besar dari nilai $r$ tabel, maka variabel dikatakan valid. Namun jika nilai corrected item total correlation lebih kecil dari nilai $r$ tabel, maka variabel dikatakan tidak valid. Karena variabel-variabel nilai corrected item total correlation pada peneitian ini lebih besar dari nilai $r$, dapat disimpulkan bahwa kuesioner yang diuji valid. 
Tabel 4. Output Uji Reabilitas

\begin{tabular}{|r|r|}
\hline \multicolumn{2}{|c|}{ Reliability Statistics } \\
\hline $\begin{array}{c}\text { Cronbach's } \\
\text { Alpha }\end{array}$ & N of Items \\
\hline .824 & 8 \\
\hline
\end{tabular}

Sumber : Hasil olahan penulis, 2017

Nilai $r$ dicari menggunakan tabel $r$ uji dua sisi dengan level signifikan 0.05. Untuk jumlah data (n) sebanyak 30, diperoleh nilai $r$ tabel sebesar 0.361 (Lihat tabel $r$ pada lampiran ke 7). Nilai $r$ ini dibandingkan dengan nilai cronbach's alpha output. Jika nilai cronbach's alpha lebih besar dari nilai $r$, maka kuesioner dikatakan reliabel.

\section{Uji Normalitas}

Uji normalitas digunakan untuk mengetahui sebaran data penelitan pada suatu variabel, apakah terdistribusi secara normal atau tidak normal. Uji normalitas dilakukan dengan menggunakan program SPSS. Berikut ini adalah pedoman yang digunakan untuk pengambilan keputusan pada uji normalitas :

a. Nilai Sig. atau signfikansi atau nilai probabilitas $<0.05$ maka distribusi tidak normal (asimetris)

b. Nilai Sig. atau signifikansi atau nilai probabilitas $>0.05$ maka distribusi normal (simetris)

\section{Tabel 5. Output Uji Normalitas}

\begin{tabular}{|l|c|c|c|c|c|c|}
\hline & \multicolumn{3}{|c|}{ Kolmogorov-Smirnov } & \multicolumn{3}{c|}{ Shapiro-Wilk } \\
\cline { 2 - 7 } & Statistic & $\mathrm{df}$ & Sig. & Statistic & Df & Sig. \\
\hline A1 & .277 & 30 & .000 & .762 & 30 & .000 \\
C1 & .241 & 30 & .000 & .886 & 30 & .004 \\
C2 & .368 & 30 & .000 & .702 & 30 & .000 \\
D1 & .256 & 30 & .000 & .772 & 30 & .000 \\
E1 & .216 & 30 & .001 & .867 & 30 & .001 \\
F1 & .218 & 30 & .001 & .896 & 30 & .007 \\
G1 & .263 & 30 & .000 & .800 & 30 & .000 \\
G2 & .278 & 30 & .000 & .734 & 30 & .000 \\
\hline
\end{tabular}

Sumber : Hasil olahan penulis, 2017

Berdasarkan tabel di atas, tidak ada varibel yang memiliki tingkat signifikansi atau nilai probabilitas di atas 0.05. Maka disimpulkan bahwa seluruh variabel yang digunakan pada penelitian kali ini tidak berdistribusi normal.

3. Analisa Statistik Deskriptif

Tabel 6. Output Analisa Deskriptif

\begin{tabular}{|c|c|c|c|c|}
\hline & A1 & C1 & $\mathrm{C} 2$ & D1 \\
\hline Valid & 30 & 30 & 30 & 30 \\
\hline Missing & 0 & 0 & 0 & 0 \\
\hline Mean & 4.33 & 2.57 & 4.43 & 4.03 \\
\hline Median & 4.00 & 2.00 & 5.00 & 4.00 \\
\hline Mode & 5 & 2 & 5 & 5 \\
\hline Std. Deviation & .758 & 1.251 & .774 & 1.217 \\
\hline
\end{tabular}

Sumber : Hasil olahan penulis, 2017

Tabel 7. Output Analisa Deskriptif (sambungan)

\begin{tabular}{|c|c|c|c|c|c|}
\hline & E1 & F1 & G1 & $\mathrm{G} 2$ \\
\hline \multirow[t]{2}{*}{$\mathrm{N}$} & Valid & 30 & 30 & 30 & 30 \\
\hline & Missing & 0 & 0 & 0 & 0 \\
\hline \multicolumn{2}{|c|}{ Mean } & 3.57 & 2.60 & 4.20 & 4.37 \\
\hline \multicolumn{2}{|c|}{ Median } & 3.00 & 2.00 & 4.00 & 4.00 \\
\hline \multicolumn{2}{|c|}{ Mode } & 3 & 2 & 4 & $4^{\circ}$ \\
\hline \multicolumn{2}{|c|}{ Std. Deviation } & 1.194 & 1.248 & .761 & .718 \\
\hline
\end{tabular}

Sumber : Hasil olahan penulis, 2017

Berdasarkan hasil data perhitungan di atas, didapat bahwa sebaran nilai rata-rata (mean) berada pada kisaran nilai 2 hingga 4 dengan nilai terkecil berada pada sub variabel F1 (penggunaan material modular atau prafabrikasi) dengan nilai mean 2.60. Secara garis besar variabel bebas (independent) pada penelitian ini memberikan pengaruh pada varibael terikat (dependent), sehingga dari kategori aspek material resources and cycle sesuai standar green building, sub variabelnya telah diterapkan pada proyek bangunan gedung yang ditinjau.

\section{Uji Korelasi dan Regresi}

Analisa korelasi spearman yang dilakukan pada penelitian ini bertujuan untuk mengetahui seberapa besar korelasi antar variabel. Angka korelasi diatas 0,5 menunjukkan korelasi kuat, sedangkan di bawah 0,5 menunjukkan korelasi lemah. 
Tabel 8. Output Uji Korelasi

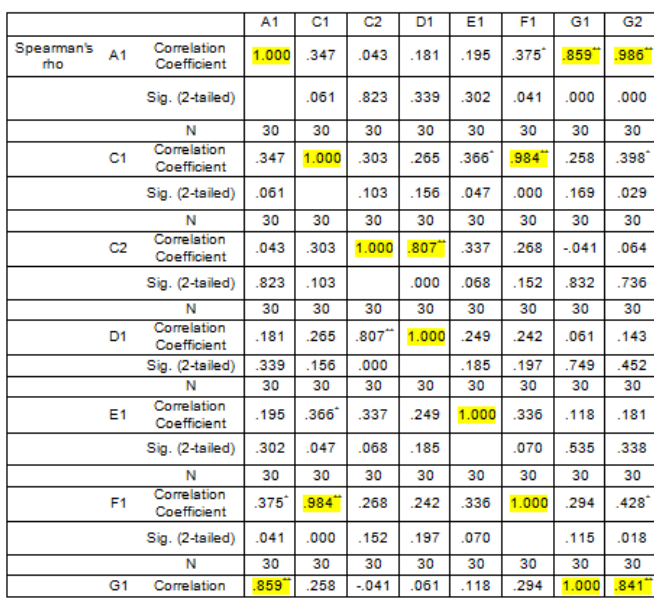

Sumber : Hasil olahan penulis, 2017

Tabel 9. Output Uji Korelasi (sambungan)

\begin{tabular}{|c|c|c|c|c|c|c|c|c|c|}
\hline \multicolumn{2}{|r|}{ Coeffil } & & & & & & & & \\
\hline & Sig. (2-tailed) & .000 & .169 & .832 & .749 & .535 & .115 & & .000 \\
\hline & $\mathrm{N}$ & 30 & 30 & 30 & 30 & 30 & 30 & 30 & 30 \\
\hline G2 & 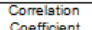 & $.986^{\circ}$ & $.398^{\circ}$ & .064 & .143 & .181 & $.428^{\circ}$ & $.841^{\circ}$ & 1.000 \\
\hline & Sig. (2-tailed) & .000 & .029 & .736 & .452 & .338 & .018 & .000 & \\
\hline & $\mathrm{N}$ & 30 & 30 & 30 & 30 & 30 & 30 & 30 & 30 \\
\hline
\end{tabular}

Sumber : Hasil olahan penulis, 2017

Analisa Regresi pada penelitian ini menggunakan regresi linier berganda dengan bantuan program SPSS. Regresi linier berganda adalah regresi untuk lebih dari 1 variabel independent dengan 1 variabel dependent. Uji regresi dilakukan untuk mengetahui arah hubungan antara variabel independen dengan variabel dependen apakah masing-masing variabel independen berhubungan positif atau negatif dan untuk memprediksi nilai dari variabel dependen apabila nilai variabel mengalami kenaikan atau penurunan juga untuk melihat variabel manakah yang lebih dominan diantara 3 sub variabel tersebut.
Tabel 10. Kategori Dominan Aspek Sumber dan Siklus Material dengan nilai korelasi kuat.

\begin{tabular}{|c|c|c|c|}
\hline $\begin{array}{c}\text { Sub- } \\
\text { variabel }\end{array}$ & \multicolumn{1}{|c|}{ Kategori Aspek } & $\begin{array}{c}\text { Adjusted R } \\
\text { square }\end{array}$ & Peringkat \\
\hline A1 & $\begin{array}{l}\text { Penggunaan refrigeran non- } \\
\text { chloro fluoro carbon (CFC) dan } \\
\text { pemadam kebakaran non- } \\
\text { halon) }\end{array}$ & 0.961 & 1 \\
\hline G2 & $\begin{array}{l}\text { Penggunaan material yang } \\
\text { lokasi asal bahan baku utama } \\
\text { atau fabrikasinya berada dalam } \\
\text { wilayah RI }\end{array}$ & 0.951 & 2 \\
\hline G1 & $\begin{array}{l}\text { Penggunaan material yang } \\
\text { lokasi asal bahan baku utama } \\
\text { ataus fabrikasinya berada di } \\
\text { dalam radius } 1.000 \text { km dari } \\
\text { lokasi proyek }\end{array}$ & 0.752 & 3 \\
\hline
\end{tabular}

Sumber : Hasil olahan penulis, 2017

5. Hasil Validasi Penelitian

Setelah didapat 3 persamaan regresi dari uji regresi diatas, tahap terakhir adalah dilakukan validasi hasil penelitian dengan cara penyebaran kuesioner kembali kepada 3 responden (R31, R32 dan R33) dengan tujuan untuk mencari kesamaan nilai ratarata dari hasil validasi penelitian dengan hasil rata-rata pada 30 responden dianalisa data tahap kedua dengan mengacu terhadap nilai adjusted $r$ square dari output korelasi masing-masing sub variabelnya. Jika kedua nilai rata-rata tersebut menghasilkan nilai yang sama dan dalam skala likert menunjukkan setuju maka dapat dikatakan analisa data pada kuesioner ini dapat dipercaya atau terbukti benar, dimana skala tersebut adalah :

$1=$ tidak setuju

2 = kurang setuju

3 = cukup setuju

$4=$ setuju

5 = sangat setuju

Dengan demikian dapat disimpulkan bahwa kategori aspek material resources and cycle objek bangunan gedung yang ditinjau telah sesuai dengan persyaratan pada standar sistem green building rating tool for new building version 1.2, dengan penjabaran sebagai berikut :

- Variabel A1 = Nilai rata-rata hasil validasi $=4.9$

Nilai rata-rata hasil sampel $=4.3$ 
Nilai adjusted $r$ square $\quad=0.961$

Yang mengandung pengertian bahwa adanya pengaruh sub variabel $\mathrm{G} 2, \mathrm{E} 1, \mathrm{C} 2$, C1, D1, G1 dan F1 (independen) terhadap variabel A1 (dependen) adalah sebesar 96.1\%.

- Variabel G2 = Nilai rata-rata hasil

$$
\text { validasi }=4.5
$$

Nilai rata-rata hasil sampel $=4.4$

Nilai adjusted $r$ square $\quad=0.951$

Yang mengandung pengertian bahwa adanya pengaruh sub variabel G2, E1, C2, C1, D1, A1 dan F1 (independen) terhadap variabel G1 (dependen) adalah sebesar 95.1\%.

- Variabel G1 = Nilai rata-rata hasil validasi $=4.4$

Nilai rata-rata hasil sampel $=\mathbf{4 . 2}$

Nilai adjusted $r$ square $\quad=0.752$

Yang mengandung pengertian bahwa adanya pengaruh sub variabel $\mathrm{G} 1, \mathrm{C} 2, \mathrm{E} 1$, F1, D1, A1 dan C1 (independen) terhadap variabel G2 (dependen) adalah sebesar $75.2 \%$.

\section{Kesimpulan}

Berdasarkan dari hasil pengujian analisa data pada penelitian ini, dapat disimpulkan bahwa :

Proyek bangunan gedung yang ditinjau telah menerapkan konsep bangunan ramah lingkungan dari segi aspek Material Resources And Cycle (Sumber dan Siklus Material) sesuai dengan standar green building rating tool for new building version 1.2, karena adanya korelasi / saling berpengaruh antara variabel bebas (kategori aspek material resources and cycle) dengan variabel terikat (kategori aspek yang telah diterapkan pada proyek bangunan gedung yang ditinjau). Hasil tersebut sesuai dengan analisa data yang telah dilakukan pada bab sebelumnya.

\section{Daftar Pustaka}

Adkon, Riduwan. (2006). Metode Teknis Menyusun Tesis. Bandung: Alfabeta. (dalam Ryan Ariefasa BAB IV tabel tingkat reabilitas. Skripsi Universitas Indonesia, (2011).

Ashby, M., Shercliff, H., \& Cebon, D. (2007). Materials - Engineering, Science, Processing and Design.(dalam Zidni Auliya. "Pengaruh Material Resources and Cycle Terhadap Biaya Konstruksi Green Building dibandingkan dengan Conventional Building". Tugas Akhir Teknik Sipil Universitas Indonesia Juni, (2012).

Chen, Henry. (2008). Green building, solusi mengatasi pemanasan global Indonesia Design, 5, 91-93. (dalam Zidni Auliya. "Pengaruh Material Resources and Cycle Terhadap Biaya Konstruksi Green Building dibandingkan dengan Conventional Building". Tugas Akhir Teknik Sipil Universitas Indonesia Juni, (2012).

Dreepaul, R. Alternative Refrigerants. Institut Superieur de Technologie. (dalam Zidni Auliya. "Pengaruh Material Resources and Cycle Terhadap Biaya Konstruksi Green Building dibandingkan dengan Conventional Building". Tugas Akhir Teknik Sipil Universitas Indonesia Juni, (2012).

Ervianto, W. (2012). Selamatkan Bumi Melalui Konstruksi Hijau. Yogyakarta: Penerbit Andi. (dalam Dian Suci Wulandari Ningrum. "Penerapan Reuse Material Bekas Sebagai Bahan Material Pada Bangunan". Jurnal Teknil Arsitektur USU Medan.

Febrian Pratama Poetra Setiawan, Grace Erny Gazali, Paulus Nugraha, Sandra Loekita. "Survei Tingkat Kepentingan Dan Penerapan Sumber Dan Siklus Material Dari Greenship Rating Tools 
Pada Proyek Konstruksi". Jurnal Teknik

Sipil Vol. 3 No. 2, (2014).

Green Building Council Indonesia. 2014.

Panduan Teknis Perangkat Penilaian

Bangunan Hijau Untuk Bangunan Baru

Versi 1.2. Jakarta: Green Building

Council Indonesia.

Lembaga Ekolabel Indonesia. (2009).

Sertifikasi untuk Keadilan dan

Kelestarian: http://www.lei.or.id/id.

(dalam Zidni Auliya. "Pengaruh Material

Resources and Cycle Terhadap Biaya

Konstruksi Green Building

dibandingkan dengan Conventional

Building". Tugas Akhir Teknik Sipil

Universitas Indonesia Juni, (2012).

Peraturan Menteri Negara Lingkungan

Hidup Nomor 8 Tahun 2010 Tentang

Kriteria dan Sertifikasi Bangunan

Ramah Lingkungan Bab I Pasal 1.

Peraturan Menteri Negara Lingkungan Hidup Nomor 8 Tahun 2010 Tentang Kriteria Bangunan Ramah Lingkungan Bab II Pasal 4.

Peraturan Menteri Peridustrian Republik Indonesia Nomor 33/MIND/PER/4/2007 tentang Larangan Memproduksi Bahan Perusak Lapisan Ozon Serta Memproduksi Barang Yang Menggunakan Bahan Perusak Lapisan Ozon Pasal I.

Pitts, Adrian (2004), Planning and design strategies for sustainability and profit:Pragmatic sustainable design on building and urban scales. United Kingdom: Architectural Press.(dalam Zidni Auliya. "Pengaruh Material Resources and Cycle Terhadap Biaya Konstruksi Green Building dibandingkan dengan Conventional Building". Tugas Akhir Teknik Sipil Universitas Indonesia Juni, (2012).

Priatman, Jimmy. (2008). Suistainable construction. Rumah Ide, 18-19.(dalam
Zidni Auliya. "Pengaruh Material Resources and Cycle Terhadap Biaya Konstruksi Green Building dibandingkan dengan Conventional Building". Tugas Akhir Teknik Sipil Universitas Indonesia Juni, (2012).

Saaty. (2008). Tabel indeks konsistensi random (RI). (dalam Ryan Ariefasa BAB IV tabel tingkat reabilitas. Skripsi Universitas Indonesia, (2011).

Sugiyono. (2009). Metode Penelitian Kuantitatif, Kualitatif dan $R$ \& D. Bandung: Alfabeta.(dalam Guruh Rahmat Gumilar BAB III Metodologi Penelitian. Tugas Akhir Universitas pendidikan Indonesia, (2013).

Surya Arafat, Nur Rahmawati Syamsiyah. "Performansi Greenship Building Pada Rumah Turi Di Surakarta (Penekanan Pada Water Conservation Dan Material Resources And Cycle)". Jurnal Vol. 13 No. 1, (2013).Zidni Auliya. "Pengaruh Material Resources and Cycle Terhadap Biaya Konstruksi Green Building dibandingkan dengan Conventional Building". Tugas Akhir Teknik Sipil Universitas Indonesia Juni, (2012).

http://www.pollutionissues.com/Br-

Co/CFCs-Chlorofluorocarbons.html.

(Sabtu, 1 April 2017). Ennis, C. A. (2009). Br-Co: CFCs (Chlorofluorocarbons). https://afidburhanuddin.wordpress.com/2 013/05/21/pengumpulan-data-daninstrumen-penelitian/.(Sabtu, 1 April 2017). Arikunto, Suharsimi. (2010). Prosedur Penelitian Suatu Pendekatan Praktik. Jakarta: Rineka Cipta.

http://www.seputarpendidikan.com/2016 /03/19-pengertian-metodologipenelitian-menurut-paraahli.html.(Sabtu 1 April 2017).

http://listatalis.blogspot.co.id/2014/12/vbehaviorurldefaultvmlo.html. (Sabtu 1 
April 2017). Pengertian variabel penelitian menurut Sugiyono. (2012).

http://qmc.binus.ac.id/2014/11/01/u-j-iv-a-l-i-d-i-t-a-s-d-a-n-u-j-i-r-e-l-i-a-b-i-li-t-a-s/. (Sabtu 1 April 2017). Pengertian validitas menurut Azwar (1986).

http://qmc.binus.ac.id/2014/11/01/u-j-iv-a-l-i-d-i-t-a-s-d-a-n-u-j-i-r-e-l-i-a-b-i-li-t-a-s/. (Sabtu 1 April 2017). Fungsi uji validitas menurut Ghozali (2009).

http://qmc.binus.ac.id/2014/11/01/u-j-iv-a-l-i-d-i-t-a-s-d-a-n-u-j-i-r-e-l-i-a-b-i-li-t-a-s/. (Sabtu 1 April 2017). Reabilitas menurut Suryabrata, Sumadi. (2004: 28).

https://environment-indonesia.com/apaitu-iso-14001/, Selasa 25 Juli 2017). Manfaat sertifikasi ISO 14001 bagi lingkungan. 